\title{
Analysis of the possibilities for improvement of thermal comfort of living quarters located in multi-family large-panel prefabricated buildings
}

\author{
Konrad Podawca ${ }^{1,}{ }^{*}$, Agata Pawłat-Zawrzykraj ${ }^{1}$, and Marek Dohojda ${ }^{1}$ \\ ${ }^{1}$ Warsaw University of Life Sciences -SGGW, Faculty of Civil and Environmental Engineering, \\ Department of Civil Engineering, Nowoursynowska 159, 02-776 Warsaw, Poland
}

\begin{abstract}
The article discusses the issue of low thermal insulation of partitions in large-panel prefabricated buildings. They were constructed mainly in the 70's and the 80's of the twentieth century. Defects related to freezing as well as vertical and horizontal joints of prefabricated walls, began to appear as early as in the very first years of operation. It was very burdensome for flat users due to lack of thermal comfort, mycological problems and rising heating costs. The thermovision analysis covered sections of panel partitions in real estate at Lazurowa Street in Warsaw, which is a four-storey multi-family building, constructed in large-panel system. The measurements were carried out in the periods of JanuaryFebruary 2016 before the thermal modernization of the building, and in January 2018 after its modernization and renovation of the flat. Before-and-after comparison of thermal insulation state was made on the basis of surface temperatures of crucial spots. Furthermore, after changes in the structure of external walls were finished, thermal comfort or discomfort in the analysed room were visualised, using graphs of the optimal temperature range of walls, ceiling and floor, depending on the air temperature in the room.
\end{abstract}

\section{Introduction}

Since large panel-system buildings (prefabricated pre-stressed concrete buildings) predominate in the Polish urban landscape, there are many questions concerning their future and ways of modernising them [1] including feasibility of modernisation approaches as implemented in Germany [2,3].

The first multi-family buildings in large-panel technology were built in 1957 at Warsaw's Jelonki district, although this technology had already been used after the First World War in the Netherlands [4]. In the beginning, the external walls were made as singlelayer, LECA (lightweight expanded clay aggregate) concrete elements (eg Szczecin system, W-70 system), then as sandwich panels (e.g. modified W-70 system or OW-T). Unfortunately, neither thermal properties nor aesthetics of such walls met the respective thermal or architectural requirements. This is an important problem because large panel-

\footnotetext{
* Corresponding author: konrad podawca@sggw.pl
} 
system buildings constructed between the 1960s and 1990s are now the main part of housing resources in Poland [5]. Therefore, the issues related to exploitation, assessment of technical condition and durability, as well as modernization, including thermal modernization, are the subjects of studies performed by both representatives of science and practice [5-10].

\section{The purpose and methods of the study}

\subsection{The purpose of the analysis}

The main purpose of the work is to present the impact of renovation and thermal modernization on the value of the surface temperature of building partitions in a living room located in a multi-family building constructed using the large panel-system.

The specific objectives are:

- to show the efficiency degree of thermal modernization in the context of improving thermal transmittance coefficient - U;

- to indicate locations of spots where heat leaks occur, indicating constructing errors of the building built using large panel-system;

- to analyze the desirability of internal insulation of gable rooms in the buildings built using large panel-system;

- to present possibility of achieving higher surface temperatures of partitions and improving thermal comfort in a room, while reducing heating units capacity.

\subsection{The study object}

The object of this research was a living room located in a flat, on the fourth, top floor of a multi-family building constructed in large panel-system in 1981, located in Warsaw at Lazurowa Street. The direct thermovision survey covered parts of building partitions in the corner room, such as:

- east and south external walls;

- flat roof over the analyzed room.

The choice of the research object was due to the following factors:

- construction of the building in large panel-system;

- a 35-year period of use and operation of the building;

- thermal discomfort reported by flat owners;

- renovation of the flat, including insulation of an external wall from the inside of the analyzed room using Geothene $G$ panels and replacement of a radiator (implementation in July-August 2016);

- thermal modernization of gable walls of the building in June-July 2017. 


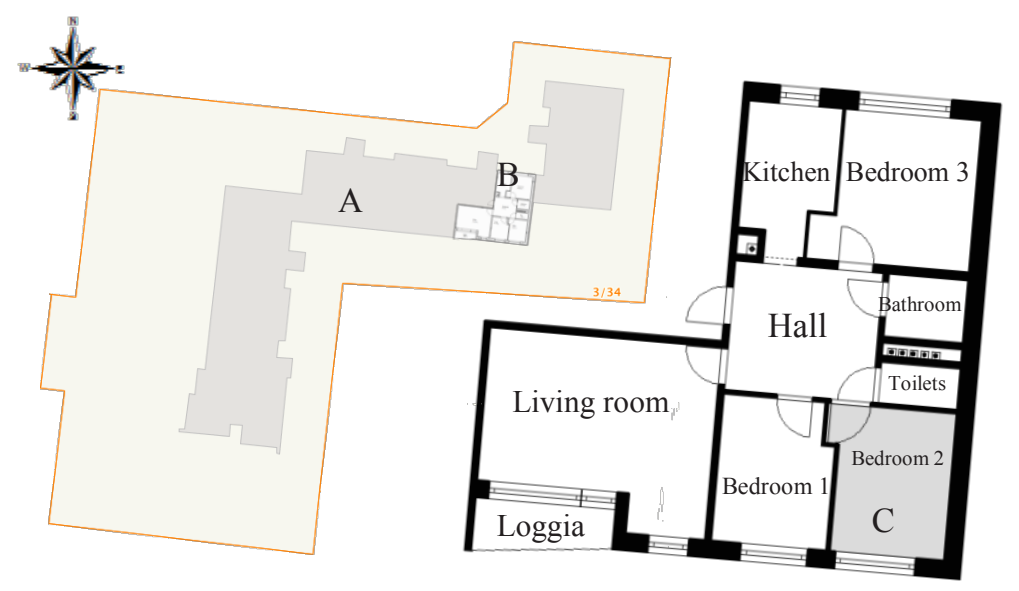

Fig. 1. Location of the study subject: A - the multi-family building constructed in large panel-system located on the lot No. 3/34, geodetic district 6-11-12 at Lazurowa Street in Warsaw, B - the flat located on the $4^{\text {th }}$, top floor, $\mathrm{C}$ - the analyzed living quarter (own elaboration).

\subsection{Methods}

The basis of the research was thermovisual analysis, which consists on remote and noncontact assessment of the temperature distribution on the surface of an examined body. This method involves observation and recording of the distribution of infrared radiation emitted by each body whose temperature is higher than the absolute zero and the conversion of the radiation to visible light.

The thermographic scanning, including thermograms that present the thermal field on the surface, was performed using ThermaCAM FLIR T-200 infrared camera and an auxiliary instrument of Flir C-2 infrared camera. The measurements carried out took into account the provisions of the PN-EN 13187 standard "Thermal properties of the building quality detection of thermal defects in the building envelope - infrared method" [11].

The research was carried out inside of the flat, at $\varepsilon=0.95$, in two stages, before and after the thermal modernization of the building and the housing unit:

- on 26 January 2016 between 3 and 4 pm, with an internal temperature of $24.6^{\circ} \mathrm{C}$ and humidity of $45 \%$, outside temperature of $4^{\circ} \mathrm{C}$, relative humidity $85 \%$, solid overcast and weak wind;

- on 11 January 2018 between 3.30 and $4.30 \mathrm{pm}$, with an internal temperature of $23^{\circ} \mathrm{C}$ and humidity of $44 \%$, outside temperature of $3^{\circ} \mathrm{C}$, relative humidity $79 \%$, solid overcast and light wind.

The similarity of inside and outside environment conditions in both respective test periods give grounds for considering the results as valid. The temperature difference between two sides of the partition was $20^{\circ} \mathrm{C}$. In addition, the lack of rainfall and solid overcast eliminated any influence of direct solar radiation.

Determining the hygrothermal parameters and properties of the partition was based on basics of building physics, including the PN-EN ISO 6946 standard [12] as main reference and relevant subject literature [13]. The ArCadia Termo software was used in the analysis.

In simplified terms, thermal comfort is a condition in which human body has a sense of an appropriate energy balance. This is related to the state in which no coldness or excessive heat is being felt, in most cases it is directly linked to the ambient temperature.

In addition to the ambient temperature, many other factors influence thermal comfort levels. The assumed, most important parameters of global comfort were: PMV (Predicted 
Mean Vote) - predicted average rating, expressed on a scale from -3 to +3 and PPD (Predicted Percentage of Dissatisfied), i.e. the predicted percentage of dissatisfied people.

[14] The indicators of local comfort or discomfort include, among others:

- predicted percentage of people dissatisfied with draughts,

- predicted percentage of people dissatisfied with the temperature difference between their head and the ankles,

- predicted percentage of people dissatisfied with floor temperature [15].

The above-mentioned indicators are influenced by:

- man-made heat,

- type and insulation of clothing and the type of physical activity performed,

- air flow speed,

- air humidity,

- $\quad$ surface temperature of building partitions [16-17].

The study focused only on the last factor. On the basis of the subject literature it was assumed, that comfort temperature for lightly dressed and resting man is at $23-26^{\circ} \mathrm{C}$, with 50\% humidity and the same wall and air temperature [16]. The correlation between temperature of air and surface of surrounding building partitions (walls, floors, ceilings) in relation to human perception of thermal comfort is presented in the König diagram, which was used to interpret the test results.

\section{Results}

In order to provide test results, the parameters of the east gable wall, which has been thermally modernized, should be characterized first. Data concerning the wall's structure, as well as features and properties of individual layers, have been derived from technical documentation $[18,19]$. They are presented in Table 1.

Table 1. Parameters for east external gable wall, before and after thermal modernization (own elaboration based on reports from the ArCADia-Termo).

\begin{tabular}{|c|c|c|c|c|c|c|c|}
\hline \multirow{2}{*}{ Type of a layer } & d & $\lambda$ & $\mu$ & $\mathbf{S}_{\mathrm{d}}$ & R-I & R-II & R-III \\
\hline & {$[\mathrm{m}]$} & {$[\mathrm{W} / \mathrm{m} \cdot \mathrm{K}]$} & {$[-]$} & {$[\mathrm{m}]$} & {$\left[\mathrm{m}^{2} \cdot \mathrm{K} / \mathrm{W}\right]$} & {$\left[\mathrm{m}^{2} \cdot \mathrm{K} / \mathrm{W}\right]$} & {$\left[\mathrm{m}^{2} \cdot \mathrm{K} / \mathrm{W}\right]$} \\
\hline External side $\mathrm{R}_{\mathrm{se}}$ & & 0.040 & 0.040 & 0.040 \\
\hline Trapezoidal metal sheets & 0.001 & 50,00 & $10^{6}$ & 1000 & 0.000 & - & - \\
\hline Mineral plaster e.g. BOLIX MP & 0.003 & 1.000 & 71 & 0.21 & - & 0.003 & 0.003 \\
\hline Mineral wool & 0.06 & 0.050 & 2 & 0.12 & 1.200 & - & - \\
\hline Styrofoam boards Knauf Term & 0.12 & 0.031 & 60 & 7.20 & - & 3.871 & 3.871 \\
\hline Sandwich panel, pre-fabricated & 0.26 & 1.700 & 24 & 6.24 & 0.153 & 0.153 & 0.153 \\
\hline Cement-lime plaster & 0.02 & 0.820 & 16 & 0.32 & 0.024 & 0.024 & - \\
\hline Eurothane G & 0.03 & 0.022 & $100 *$ & 3.0 & - & - & 1.364 \\
\hline Gypsum patch & 0.002 & 0.400 & 7 & 0.014 & - & - & 0.005 \\
\hline Internal side $\mathrm{R}_{\mathrm{si}}$ & & & & & 0.130 & 0.130 & 0.130 \\
\hline
\end{tabular}

* value adopted from the ArCadia-Termo corresponding to the value of $\mu$ for a core of the wall panel, according to the manufacturer's specification for the final product $\mu>17000$

The calculations of the total thermal resistance of a partition $\mathrm{R}_{\mathrm{c}}$, thermal transmittance coefficient $U_{c}$, wall's temperature coefficient $f_{\text {Rsi }}$ were made for a critical month and environmental conditions witnessed during test periods. The internal and external conditions existing during the measurements and small number of flat residents, were taken into account during computations. The results are presented in Table 2. 
Table 2. The comparison of the characteristics for external east gable wall, before and after thermal modernization (own elaboration based on reports from the ArCADia-Termo).

\begin{tabular}{|c|c|c|c|}
\hline Characteristic & Wall I & Wall II & Wall III \\
\hline Partition thickness $[\mathrm{m}]$ & $0.40^{*}$ & 0.40 & 0.41 \\
\hline $\begin{array}{l}\text { Total thermal resistance of a partition } \\
\qquad R_{c}\left[m^{2} \cdot K / W\right]\end{array}$ & 1.547 & 4.221 & 5.566 \\
\hline $\begin{array}{l}\text { thermal transmittance coefficient } \\
\mathrm{U}\left[\mathrm{W} /\left(\mathrm{m}^{2} \cdot \mathrm{K}\right)\right] \text { of a partition }\end{array}$ & 0.646 & 0.237 & 0.180 \\
\hline thermal resistivity coefficient of a partitions $\mathrm{f}_{\mathrm{Rsi}}$ & 0.916 & 0.969 & 0.977 \\
\hline $\begin{array}{l}\text { Thermal resistivity coefficient for a critical } \\
\text { month (January) f Rsi,max }\end{array}$ & 0.678 & 0.678 & 0.678 \\
\hline Condition $\mathrm{f}_{\mathrm{Rsi}} \geq \mathrm{f}_{\mathrm{Rsi}, \max }$ & $0.916 \geq 0.678$ & $0.969 \geq 0.678$ & $0.977 \geq 0.678$ \\
\hline $\begin{array}{l}\text { Value of the room temperature coefficient for the } \\
\text { measurement conditions } f_{\text {Rsi }}\end{array}$ & 0.590 & 0.590 & 0.590 \\
\hline Correctly designed partitions to avoid mould & yes & yes & yes \\
\hline $\begin{array}{l}\text { Correctly designed partitions to avoid water } \\
\text { vapour condensation }\end{array}$ & yes & yes & yes \\
\hline
\end{tabular}

* trapezoidal metal sheets thickness is taken into account

The values of average surface temperatures of building partitions in characteristic spots, before and after renovation and thermal modernization activities, were presented on the basis of the prepared thermograms (Table 3, Figures 2-3).

Table 3. The comparison of average surface temperatures in characteristic spots of the analyzed room before and after thermal modernization (own elaboration).

\begin{tabular}{|c|c|c|c|c|c|}
\hline \multirow{2}{*}{$\begin{array}{c}\text { Type of } \\
\text { partition }\end{array}$} & \multirow{2}{*}{ Location of the measurements spots } & \multirow{2}{*}{ No } & \multicolumn{3}{|c|}{ Temperature $\left[{ }^{\circ} \mathbf{C}\right]$} \\
\hline & & & before* & after** & $\Delta \mathrm{T}$ \\
\hline \multirow{3}{*}{$\begin{array}{l}\text { South } \\
\text { external wall }\end{array}$} & $\begin{array}{l}\text { west corner on the joints of south and } \\
\text { west walls with the ceiling }\end{array}$ & 1 & 17.5 & 21.0 & 3.5 \\
\hline & joint between the wall and the ceiling & 2 & 16.5 & 19.0 & 2.5 \\
\hline & around a window & 3 & 18.0 & 22.0 & 4.0 \\
\hline \multirow{4}{*}{$\begin{array}{l}\text { East } \\
\text { external wall }\end{array}$} & $\begin{array}{r}\text { east corner on the jo } \\
\text { west walls witl }\end{array}$ & 4 & 14.5 & 16.8 & 2.3 \\
\hline & surface of the wall $\mathrm{v}$ & 5 & \multirow{2}{*}{17.5} & 19.1 & 1.6 \\
\hline & surface of the wall with Geote & 6 & & 21.9 & 4.4 \\
\hline & $\begin{array}{l}\text { edge of joints between the wall and the } \\
\text { ceiling }\end{array}$ & 7 & 16.5 & 19.0 & 2.5 \\
\hline $\begin{array}{c}\text { South } \\
\text { internal wall }\end{array}$ & $\begin{array}{l}\text { surface of the wall between the room a } \\
\text { toilet ( without a radiator) }\end{array}$ & 8 & 20.0 & 23.1 & 3.1 \\
\hline $\begin{array}{c}\text { West } \\
\text { internal wall }\end{array}$ & surface of the wall between rooms & 9 & 21.0 & 23.0 & 2.0 \\
\hline Ceiling & & 10 & 20.5 & 22.5 & 2.0 \\
\hline Floor & in its central point & 11 & 21.0 & 22.8 & 1.8 \\
\hline
\end{tabular}

*before thermal modernization and renovation, ** after thermal modernization and renovation 


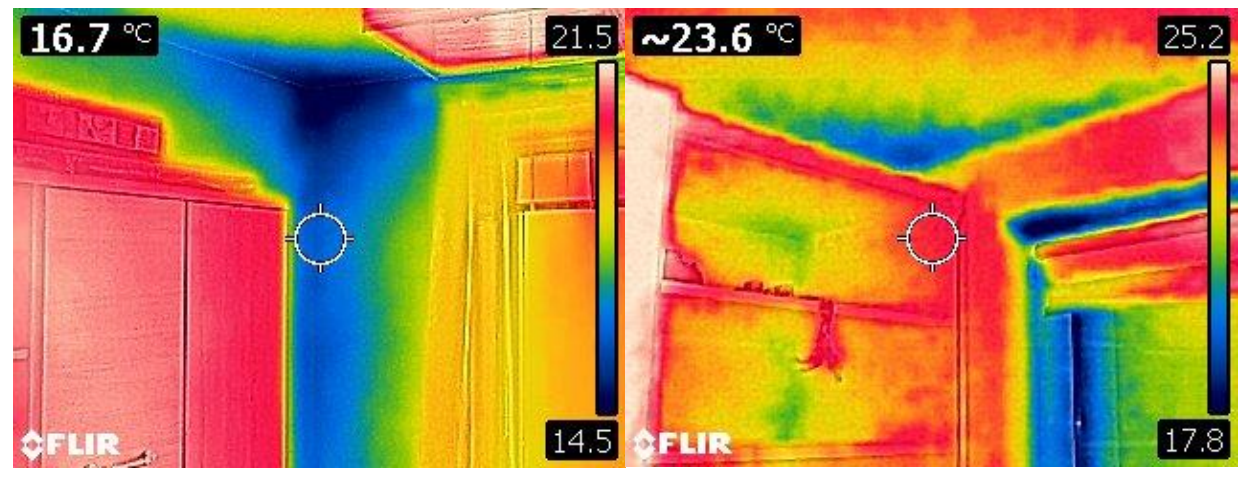

Fig. 2. Thermal image of the corner of the east gable wall south external wall and the ceiling (own elaboration).

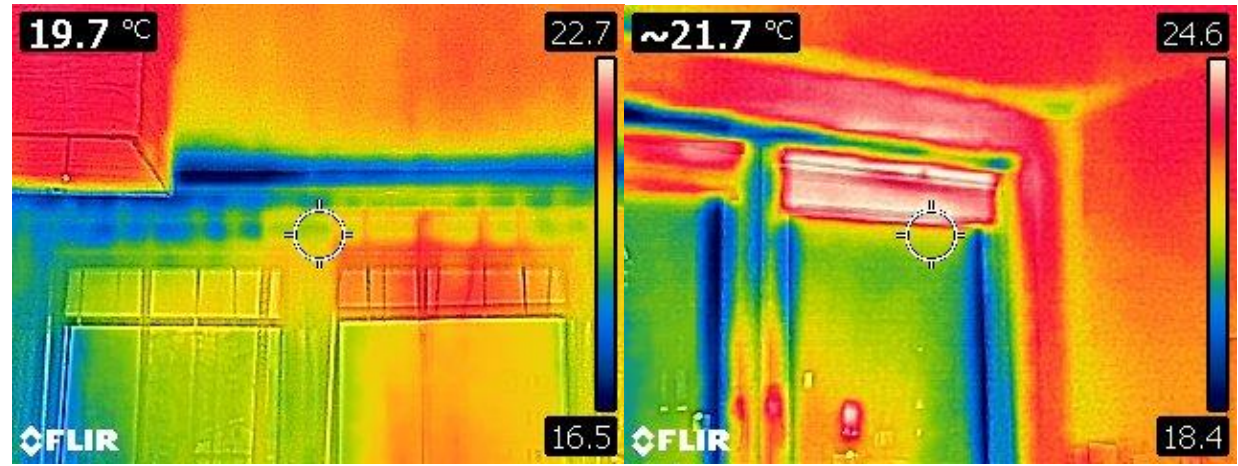

Fig. 3. Thermal image for the joint of the external south wall and the flat roof before and after applying Eurothane G panels (own elaboration).

\section{Results}

With regards to the objectives the following conclusions have been formulated:

- Before thermal modernization, the gable wall did not provide sufficient thermal insulation $(U=0.646)$, temperature differences registered between the surface of the walls, their edges and ceiling were even above $14^{\circ} \mathrm{C}$, which clearly indicates errors in the construction of the object, probably due to discontinuity or degradation of the insulation material at ventilated flat roof, in the wall-ceiling connection, on the eastern and gable walls as well as on the corner of external, south and east walls;

- After thermal modernization, the insulation of the gable wall has increased; unfortunately, the U-value of $0.237 \mathrm{~W} / \mathrm{m}^{2} \mathrm{~K}$ did not reach the $\mathrm{U}$ coefficient's maximum value valid from 1 January 2017 (equal to $\mathrm{U}_{\max }=0.23 \mathrm{~W} / \mathrm{m}^{2} \mathrm{~K}$ ), which could be a result of preparing the implementation documentation in 2015, when $\mathrm{U}_{\max }$ was assumed at $0.25 \mathrm{~W} / \mathrm{m}^{2} \mathrm{~K}$;

- After renovation and thermal modernization, the value of thermal transmittance coefficient has decreased by 0.057 , which proves the use of the Eurothane $G$ panels from the inside was justified;

- Internal insulation of the east and south walls with Eurothane G panels moved the edge connecting the wall and flat roof $3 \mathrm{cms}$ towards the interior of the room, which increased the surface temperature in this place by about $2.5^{\circ} \mathrm{C}$; it is a small value compared to the increase of temperature on the surface around windows and on fragments of walls with Eurothane $\mathrm{G}$ panel (over $4^{\circ} \mathrm{C}$ ); 
- Thermal modernization and renovation of the room have had an impact on the change of surface temperatures of internal partitions, but to a lesser extent, with an increase of approx. $2^{\circ} \mathrm{C}$;

- Renovation of the flat and thermal modernization of the gable wall excluding thermal modernization of the flat roof, resulted in limited success - very low temperatures registered in the east corner, between the east and south walls and ceiling are the best evidence;

- Thermovision measurements have clearly indicated spots with reduced temperature, especially in joins between prefabricated wall panels or such walls and ceiling panels;

- The results of the measurements confirmed, that before thermal modernization of the building, in order to achieve thermal comfort in the room it was necessary to heat it up substantially, which caused high heating costs;

- Irrespective of the existing mistakes introduced during the construction of the multifamily building, renovation of the room and thermal modernization of the building brought significant changes in individual measurement results of wall, ceiling and floor surface temperature in the tested room, thus improving the thermal perception by its residents with less intensive heating requirements;

- The number of units from heat cost allocators pointed out, for the analogical measuring periods - reduction in indications by $1 / 3$.

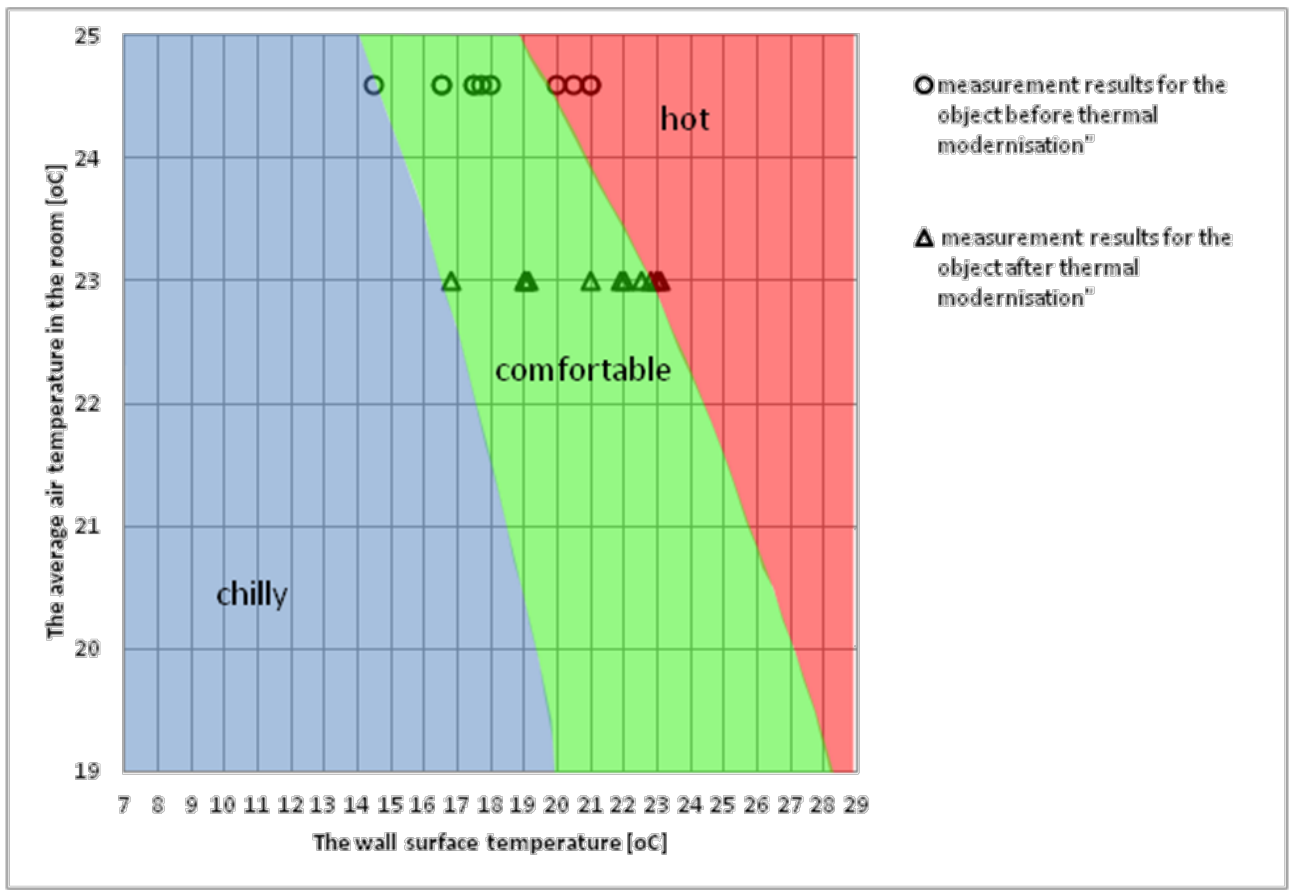

Fig. 4. Heating comfort in the analysed room, 1-11 measurement points according to the Table 3, $\circ$ - before thermal modernisation, $\Delta$ - after thermal modernization (own elaboration).

\section{References}

1. B.E. Gronostajska, Architecturae et Artibus 2, 19-26 (2010)

2. A. Mettke, Tagungsband Alte Platte-Neues Design - Die Platte lebt, Fachtagung am 16/17.02.2005 an der BTU Cottbus, 1-196 (2005) 
3. B.E. Gronostajska, Czasopismo Techniczne, Architektura 14, 142-147 (2011)

4. K. Piechotek, M. Piechotek, Jak budowano wielka plytę, „Newsweek.pl” (2010) [dostęp 2017-06-16]

5. J. Sobczak-Piąstka, A. Podhorecki, Inżynier Budownictwa 2, 78-86 (2014)

6. L. Runkiewicz, B. Szudrowicz, R. Geryło, J. Szulc, J. Sieczkowski, Przegląd Budowlany 9, 20-26 (2014)

7. P. Knyziak, Nieprawidłowe użytkowanie i modernizowanie głównymi zagrożeniami trwałości budynków z wielkiej ptyty, w: Awarie budowlane. Zapobieganie, diagnostyka, naprawy, rekonstrukcje, red. M. Kaszyńska, Zachodniopomorski Uniwersytet Technologiczny w Szczecinie, 283-294 (2017)

8. K. Nowak-Dzieszko, J. Dębowski, Technical Transactions Civil Engineering 3-B, 363-370 (2014)

9. $\check{C}$. Ignatavičius, E.K. Zavadskas, L. Ustinovičius, The $9^{\text {th }}$ International Conference "Modern Building Materials, Structures and Techniques", Ed. by M.J. Skibniewski, P. Vainiunas, E.K. Zavadskas, May 16-18, 2007, Vilnius, Lithuania. Vilnius: Technika 1-3, 258-264 (2007)

10. P. Pihelo, T. Kalamees, K. Kuusk, IOP Conf. Series: Materials Science and Engineering 251, 1, 012056 (2017)

11. PN-EN 13187:2001 "Właściwości cieplne budynku -jakościowa detekcja wad cieplnych w obudowie budynku -metoda podczerwieni"

12. PN-EN ISO 6946:2008 "Komponenty budowlane i elementy budynku - Opór cieplny $i$ współczynnik przenikania ciepła - Metoda obliczania"

13. A. Dylla, Fizyka cieplna budowli w praktyce-obliczenia cieplno-wilgotnościowe (Wydawnictwo Naukowe PWN, Warszawa, 2015)

14. PN-EN ISO 7730:2006 "Ergonomia środowiska termicznego -- Analityczne wyznaczanie $i$ interpretacja komfortu termicznego $z$ zastosowaniem obliczania wskaźników PMV i PPD oraz kryteriów miejscowego komfortu termicznego"

15. A. Bohojło, Civil and Environmental Engineering 1, 11-16 (2010)

16. I. Sudoł-Szopińska, A. Chojnacka, Bezpieczeństwo Pracy 5, 19-23 (2007)

17. K. Podawca, Acta Scientiarum Polonorum. Architectura 17, 1, 35-44 (2018)

18. Projekt budowlano-wykonawczy remontu fragmentów elewacji wraz z cokołem. Wielorodzinny budynek mieszkalny, ul. Lazurowa 20A, Warszawa. Pracownia projektowa Lidia Zielińska, Warszawa, marzec 2015 r.

19. Projekt budowlany docieplenia części cokołowej elewacji i wymiany docieplenia wykonanego z wełny osłoniętej blachą na docieplenie styropianem oraz docieplenia stropodachu wraz z robotami towarzyszącymi. Wielorodzinny budynek mieszkalny, ul. Lazurowa 20, Warszawa, Pracownia projektowa Lidia Sidz, Warszawa, kwiecień $2017 \mathrm{r}$. 